\title{
Recommendations from a Satellite Meeting
} International Symposium to commemorate the 90th anniversary of the discovery of Chagas disease,
April 11-16 1999, Rio de Janeiro, Brazil

During this symposium the standardization of the nomenclature of Trypanosoma cruzi strains was discussed, in a parallel session, with a view to facilitating the use and understanding of a common nomenclature that would serve not only taxonomists but the general community of researchers working with $T$. cruzi.

The diversity in the behavior and morphology of $T$. cruzi isolates was soon recognized after the discovery of Chagas disease. Since then a variety of biochemical and molecular techniques have revealed the great genetic diversity present in strains of this parasite. Different investigators have described this diversity by using various terms. Correlation between this diversity and the complex epidemiological and clinical manifestations of the disease has however been hindered by the lack of a common nomenclature.

Recent studies have indicated a convergence among investigators regarding the clustering of strains of $T$. cruzi, into two principal groups. This consensus, together with the report of a meeting on the standardization of methods for T. cruzi classification held in Panama (unpublished document TDR/EPICHA-TCC/85.3 Geneva, WHO, 1985), form the basis of the following recommendations.

1. Isolates and strains of $T$. cruzi should be named as recommended by the meeting on Chagas disease held in Panama [Rev Soc Bras Med Trop 18 (Supl.): 1985] and the WHO expert committee on the control of Chagas disease (WHO Technical Report Series on Control of Chagas Disease, No. 811, Geneva, 1991) (see Annex A).

2. Isolates and strains of $T$. cruzi after their characterization by molecular techniques, such as multilocus enzyme electrophoresis (MLEE) and random amplification of polymorphic DNA (RAPD), or genetic loci, such as mini exon genes and $24 \mathrm{~S} \alpha \mathrm{rDNA}$, should be classified into the principal groups as follows:

a) strains should be designated as T. cruzi I when they are equivalent to Zymodeme 1 (Miles et al. 1977, 1978, Barrett et al. 1980), Type III (Andrade 1974), Lineage 2 (Souto et al. 1996), Group 1 (Tibayrenc 1995) Ribodeme II/III (Clark \& Pung 1994) or similar;

b) strains should be designated as T. cruzi II when they are equivalent to Zymodeme 2 (Miles et al. 1977, 1978, Barrett et al. 1980), Zymodeme A (Romanha et al. 1979), Type II (Andrade 1974), Lineage 1 (Souto et al. 1996), Group 2 (Tibayrenc 1995), Ribodeme I (Clark \& Pung 1994) or similar;

c) strains that have not been previously characterized or whose characterization is uncertain can be designated as T. cruzi (without the group designation suffix);

d) the designation of apparent hybrid strains such as those classified as Chilean Zymodeme $2 b$ (Miles et al. 1984), Zymodeme B (Romanha et al. 1979), Type I (Andrade 1974), Group 1/2 typed by 24 S $\alpha$ rDNA (Souto et al. 1996), genotype 39 (Tibayrenc 1995) will be decided later after further studies. A similar situation exists for strains equivalent to Zymodeme 3 (Miles et al. 1978, 1981);

e) $T$. cruzi I and T. cruzi II will be referred to as groups, while further studies on their evolution and inter- and intra-relationships are carried out and an improved terminology is developed, such as discrete typing unit (DTU) (Tibayrenc 1998);

f) among the institutions offering identification services and listed in Annex 1 of the WHO report mentioned above, the Laboratory of Parasitic Diseases, Department of Tropical Medicine, at the Instituto Oswaldo Cruz, Fiocruz, Av. Brasil 4365, 21045-900 Rio de Janeiro, RJ, Brasil, E-mail: octaviof@gene.dbbm.fiocruz.br, tel/fax: +55-21-280.3740, has offered to type uncharacterized strains into the principal groups.

3. The editors of scientific journals should request authors to use the correct nomenclature for strains of $T$. cruzi (see Annex A) in their manuscripts and where possible designate their strains T. cruzi I, T. cruzi II, or T. cruzi.

4. A further meeting should be held to implement a strain bank(s), a web-site on the internet as well as improve the designation of strain names in this document. In the meantime the web-site of the Memórias do Instituto Oswaldo Cruz where the online version of this document will be held has offered to post a list of strains classified into groups (see Annex B) and to update the list periodically as new results are provided.

Participants: Drs Alejandro Luquetti, Aluízio Prata, Alvaro Moncayo, Alvaro Romanha, Ana Jansen, Bianca Zingales, Carlos Morel, Carlos Ponce, Egler Chiari, Elisa Cupolillo, Elisa Ponce, Felipe Guhl, Hooman Momen, José Rodrigues Coura, Mario Steindel, Michael Miles, Michel Tibayrenc, Octavio Fernandes, Riva Oliveira, Rodrigo Zeledón, Sonia Andrade, Toby Barrett, Vanize Macêdo, Zigman Brener. 


\section{ANNEX A}

Designation of isolates and strains

The code for the designation of strains and isolates should consist of four elements, separated by oblique strokes (examples of the four-element code are given in Annex B). The four elements are:

1. the kind of host animal or vector from which the strain was isolated. A four-letter code should be used, the class to which the animal belongs ( $\mathrm{M}$ for Mammalia) followed by three letters indicating the generic name of the mammalian host or 000 if the host has not yet been identified (in Annex 1 of the WHO report Table A 1.1 gives the code letters to be used for mammalian genera). The WHO report did not provide the code letters for the triatomine vector. Therefore a suggestion for the coding of the vectors is proposed in Annex C;

2. the country in which the isolation was made. The country of isolation is indicated by a two letter code (in Annex 1 of the WHO report Table A 1.2 gives the code letters to be used);

3. the year of isolation. This is indicated by the full four digits. The previous system of using only two digits does not distinguish between the year 2000 and strains whose year of isolation is unknown. These isolates should be referred to as 0000 ;

4. the laboratory designation (e. g. laboratory code and serial number).

\section{ANNEX B}

Examples of strain designations using the four-element code (followed by the T. cruzi group designation)

MHOM/CO/0000/Colombia (T. cruzi I)

MHOM/BR/1978/Sylvio-X10 (T. cruzi I)

MDID/BR/1982/Dm-28c (T. cruzi I)

TINF/CL/1945/Tulahen (T. cruzi I)

MHOM/BR/1950/Y (T. cruzi II)

MHOM/BR/1962/Berenice (T. cruzi II)

MHOM/BR/1977/Esmeraldo (T. cruzi II)

MHOM/PE/1963/Peru (T. cruzi)

MHOM/BR/1974/12-SF (T. cruzi)

MHOM/BR/1968/Can-III (T. cruzi)

ANNEX C

Suggested table of species codes for labelling T. cruzi isolates according to the insect host.

Species included

- all New World Triatominae;

\section{Species not included}

- insects other than Triatominae;

- Triatominae known only from the Old World (Linshcosteus carnifex, L. chota, L. confumus, L. costalis, L.

kali, Triatoma amicitiae, T. bouvieri, T. cavernicola, T. leopoldi, T. migrans, T. pugasi, T. sinica);

\section{Names included}

- names recognized as valid by Lent and Wygodzinsky (1979);

- names considered to be junior synonyms by Lent and Wygodzinsky (1979) but which have been in use since 1979;

- names validly published since 1979 , whether or not they have subsequently been placed in synonymy;

- for species attributed to more than one genus since 1979, each binomial is listed, but with the same specific code;

- names with incorrect spellings in Lent and Wygodzinsky (1979) have been corrected as follows: i) Dipetalogaster maximus (Uhler) is listed as Dipetalogaster maxima (Uhler) - mandatory change, article 34 (b), International Code of Zoological Nomenclature, third edition 1985 (-gaster is feminine); ii) Cavernicola pilosa Barber (incorrect original spelling) is listed as Cavernicola pilosus Barber - justified emendation, Article 32 (d) (- cola is masculine).

\section{Formation of three-letter species codes}

The following simple rules were found to be sufficient for assigning a unique code to each of the species listed.

I) The first three letters of the specific name were used (e.g. BAR for Triatoma barberi) unless this would result in duplication. 
II) If different names share an initial triplet, a letter unique to the rest of the specific name is chosen as the third letter of the triplet (e.g. COL for Triatoma costalimai and COC for Belminus costaricensis). If this is not possible, or if this would result in a triplet corresponding to the initial letters of another species on the list, one of the species is assigned a code as in I) above. Thus BRK for Triatoma brailovskyi and BRA for Triatoma brasiliensis. BRE is avoided in deference to Rhodnius brethesi and Triatoma breyeri.

III) If different species have the same specific name, the first letter of the genus is used as the third letter of the code (e.g. HEB for Belminus herreri and HEP for Panstrongylus herreri) unless the resulting triplet is preoccupied (thus LEV for Cavernicola lenti, because LEC is the code for Triatoma lecticularia).

\section{Four-letter species codes}

It is suggested that the first letter should be $\mathrm{T}$ for Triatominae rather than I for Insecta, to avoid duplication with the codes used for Leishmania isolates

\begin{tabular}{|c|c|c|c|c|c|}
\hline Species & Genus & Suggested code & Species & Genus & Suggested code \\
\hline arthuri & Psammolestes & ART & incrassata & Triatoma & INC \\
\hline arthurneivai & Triatoma & ARN & indictiva & Triatoma & IND \\
\hline barberi & Triatoma & BAR & infestans & Triatoma & INF \\
\hline bassolsae & Triatoma & BAS & jurbergi & Triatoma & JUR \\
\hline bolivari & Triatoma & BOL & laportei & Belminus & LAP \\
\hline borbai & Microtriatoma & BOR & lecticularia & Triatoma & LEC \\
\hline brailovskyi & Triatoma & BRK & lenti & Cavernicola & LEV \\
\hline brasiliensis & Triatoma & BRA & lenti & Panstrongylus & LEP \\
\hline brethesi & Rhodnius & BRT & lenti & Triatoma & LET \\
\hline breyeri & Triatoma & BRY & lignarius & Panstrongylus & LIG \\
\hline bruneri & Triatoma & $\mathrm{BRU}$ & limai & Triatoma & LIM \\
\hline carcavalloi & Triatoma & CAL & longipennis & Triatoma & LON \\
\hline carioca & Parabelminus & CAC & lutzi & Panstrongylus & LUT \\
\hline carrioni & Triatoma & CAN & maculata & Triatoma & MAC \\
\hline chinai & Panstrongylus & $\mathrm{CHI}$ & malheiroi & Alberprosenia & MAL \\
\hline circummaculata & Triatoma & CIR & mansosotoi & Microtriatoma & MAN \\
\hline coreodes & Psammolestes & COR & martinezi & Torrealbaia & MAR \\
\hline costalimai & Triatoma & $\mathrm{COL}$ & matogrossensis & Triatoma & MAG \\
\hline costaricensis & Belminus & $\mathrm{COC}$ & matsunoi & Hermanlentia & MAU \\
\hline cuspidatus & Eratyrus & CUS & matsunoi & Triatoma & MAU \\
\hline dalessandroi & Rhodnius & DAL & maxima & Dipetalogaster & MAX \\
\hline deanei & Triatoma & DEA & mazzottii & Triatoma & MAZ \\
\hline delpontei & Triatoma & DEL & megistus & Panstrongylus & MEG \\
\hline diasi & Panstrongylus & DIA & melanocephala & Triatoma & MEC \\
\hline dimidiata & Triatoma & DIM & melanosoma & Triatoma & MES \\
\hline dispar & Triatoma & DIS & mexicana & Triatoma & MEX \\
\hline domesticus & Rhodnius & DOM & mucronatus & Eratyrus & MUC \\
\hline ecuadorensis & Rhodnius & ECU & nasutus & Rhodnius & NAS \\
\hline eratyrusiformis & Triatoma & ERA & neglectus & Rhodnius & NEG \\
\hline flavida & Triatoma & FLA & neivai & Rhodnius & NEI \\
\hline funera & Triatoma & FUN & neotomae & Triatoma & NEO \\
\hline gajardoi & Mepraia & GAJ & nigromaculata & Triatoma & NIG \\
\hline galliardi & Triatoma & GAL & ninioi & Triatoma & NIN \\
\hline garciabesi & Triatoma & GAR & nitida & Triatoma & NIT \\
\hline geniculatus & Panstrongylus & GEN & obscura & Triatoma & OBS \\
\hline gerstaeckeri & Triatoma & GER & oliveirai & Triatoma & OLI \\
\hline gomeznunezi & Triatoma & GOM & pallescens & Rhodnius & PAC \\
\hline goyovargasi & Alberprosenia & GOY & pallidipennis & Triatoma & PAP \\
\hline guasayana & Triatoma & GUS & paraensis & Rhodnius & PAR \\
\hline guazu & Triatoma & GUZ & patagonica & Triatoma & PAT \\
\hline guentheri & Panstrongylus & GUE & peninsularis & Triatoma & PEN \\
\hline hegneri & Triatoma & HEG & peruvianus & Belminus & PER \\
\hline herreri & Belminus & HEB & petrochii & Triatoma & PET \\
\hline herreri & Panstrongylus & HEP & phyllosoma & Triatoma & PHY \\
\hline hirsuta & Paratriatoma & HIR & pictipes & Rhodnius & PIS \\
\hline howardi & Panstrongylus & HOW & picturata & Triatoma & PIR \\
\hline humeralis & Panstrongylus & HUM & pilosus & Cavernicola & PIL \\
\hline
\end{tabular}




\begin{tabular}{|c|c|c|}
\hline Species & Genus & Suggested code \\
\hline pittieri & Belminus & PIT \\
\hline platensis & Triatoma & PLA \\
\hline prolixus & Rhodnius & PRX \\
\hline protracta & Triatoma & PRT \\
\hline pseudomaculata & Triatoma & PSE \\
\hline recurva & Triatoma & REC \\
\hline robustus & Rhodnius & $\mathrm{ROB}$ \\
\hline rubida & Triatoma & RUD \\
\hline rubrofasciata & Triatoma & RUS \\
\hline rubrovaria & Triatoma & RUV \\
\hline rufotuberculatus & Panstrongylus & RUF \\
\hline rugulosus & Belminus & RUG \\
\hline ryckmani & Triatoma & $\mathrm{RYC}$ \\
\hline salazari & Psammolestes & SAL \\
\hline sanguisuga & Triatoma & SAN \\
\hline scabrosa & Bolbodera & SCA \\
\hline sinaloensis & Triatoma & SIN \\
\hline sordida & Triatoma & SOR \\
\hline spinolai & Mepraia & SPI \\
\hline spinolai & Triatoma & SPI \\
\hline stali & Rhodnius & STA \\
\hline tertius & Psammolestes & TER \\
\hline tibiamaculata & Triatoma & TIB \\
\hline trinidadensis & Microtriatoma & TRI \\
\hline tupynambai & Panstrongylus & TUP \\
\hline turpiali & Panstrongylus & TUR \\
\hline venosa & Triatoma & VEN \\
\hline vitticeps & Triatoma & VIT \\
\hline williami & Triatoma & WIL \\
\hline wygodzinskyi & Triatoma & WYG \\
\hline уитириси & Parabelminus & YUR \\
\hline
\end{tabular}

Notes: bibliographic references for names, descriptions and synonymies can be found in Carcavallo et al. 1998, Jurberg and Galvão 1997, Lent and Wygodzinsky 1979.

\section{REFERENCES}

Andrade SG 1974. Caracterização de cepas do Trypanosoma cruzi isoladas no Recôncavo Baiano. Rev Patol Trop 3: 65-121.

Barrett TV, Hoff RH, Mott KE, Miles MA, Godfrey DG, Teixeira R, Almeida de Souza JÁ, Sherlock IA 1980. Epidemiological aspects of three Trypanosoma cruzi zymodemes in Bahia State, Brazil. Trans R Soc Trop Med Hyg 74: 84-90.

Carcavallo R, Lent H, Galvão C 1998. Triatoma jurbergi sp. n. do Estado do Mato Grosso, Brasil (Hemiptera, Reduviidae, Triatominae) com uma atualização das sinonímias e outros táxons. Mem Inst Oswaldo Cruz 93: 459-464.

Clark CG, Pung OJ 1994. Host specificity of ribosomal DNA variation in sylvatic Trypanosoma cruzi from North America. Mol Biochem Parasitol 66: 175-179.

Jurberg J, Galvão C 1997. Hermanlentia n. gen. da Tribo Triatomini, com um rol de espécies de Triatominae (Hemiptera, Reduviidae). Mem Inst Oswaldo Cruz 92: 181-185.

Lent H, Wygodzinsky P 1979. Revision of the Triatominae (Hemiptera, Reduviidae), and their significance as vectors of Chagas disease. Bul Am Mus Nat Hist 163: 125-520.

Miles MA, Apt BW, Widmer G, Povoa MM, Schofield CJ 1984. Isoenzyme heterogeneity and numerical taxonomy of Trypanosoma cruzi stocks from Chile. Trans $R$ Soc Trop Med Hyg 78: 526-535.

Miles MA, Povoa M, De Souza AA, Lainson R, Shaw JJ, Ketteridge DS 1981. Chagas disease in the Amazon Basin. II. The distribution of Trypanosoma cruzi zymodemes 1 and 3 in Pará State, north Brazil. Trans $R$ Soc Trop Med Hyg 75: 667-674.

Miles MA, Souza A, Póvoa M, Shaw JJ, Lainson R, Toyé PJ 1978. Isozymic heterogeneity of Trypanosoma cruzi in the first autochthonous patients with Chagas disease in Amazonian Brazil. Nature 272: 819-821.

Miles MA, Toyé PJ, Oswald SC, Godfrey DG 1977. The identification by isoenzyme patterns of two distinct strain-groups of Trypanosoma cruzi circulating independently in a rural area of Brazil. Trans $R$ Soc Trop Med Hyg 71: 217-225.

Romanha AJ, Da Silva, Pereira AA, Chiari E, Kilgour V 1979. Isoenzyme patterns of cultured Trypanosoma cruzi: changes after prolonged subculture. Comp Biochem Physiol 62B: 139-142.

Souto RP, Fernandes O, Macedo AM, Campbell DA, Zingales B 1996. DNA markers define two major phylogenetic lineages of Trypanosoma cruzi. Mol Biochem Parasitol 83: 141-152.

Tibayrenc M 1995. Population genetics of parasitic protozoa and other microorganisms, p. 47-115. In JR Baker, R Mulle \& D Rollinson (eds), Advances in Parasitology, Academic Press, London.

Tibayrenc M 1998. Integrated genetic epidemiology of infectious diseases: the Chagas model. Mem Inst Oswaldo Cruz 93: 577-580. 